\title{
Polycystic Liver Disease: A Case Report
}

\author{
Randy Adiwinata*, Natalin Allorerung*, Jonathan Arifputra*, Andrea Livina*, \\ Pearla Lasut**, Bradley Jimmy Waleleng ${ }^{* * *}$, Fandy Gosal ${ }^{* * *}$, Luciana Rotty ${ }^{* * *}$, \\ Jeanne Winarta***, Andrew Waleleng ${ }^{* * *}$ Michael Tendean**** \\ *Department of Internal Medicine, Faculty of Medicine, \\ Universitas Sam Ratulangi/Prof. dr. RD Kandou Hospital, Manado \\ **Division of Hematology and Medical Oncology, Department of Internal Medicine, \\ Faculty of Medicine, Universitas Sam Ratulangi/Prof. dr. RD Kandou Hospital, Manado \\ ***Division of Gastroentero-hepatology, Department of Internal Medicine, Faculty of Medicine, \\ Universitas Sam Ratulangi/Prof. dr. RD Kandou Hospital, Manado

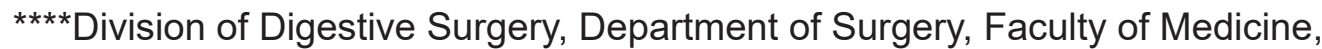 \\ Universitas Sam Ratulangi/Prof. dr. RD Kandou Hospital, Manado
}

\section{Corresponding author:}

Randy Adiwinata. Department of Internal Medicine, Faculty of Medicine, Prof. dr. R. D. Kandou Hospital. Jl.Raya Tanawangko No.56 Manado Indonesia.Phone: +62-431-7283949.Email:randyadiwinata@yahoo.com

\begin{abstract}
Polycystic liver disease is characterized by multiple cystic lesions on the liver. Liver cysts are typically incidental findings, with occasional complications including cyst hemorrhage, infection and rupture. Polycystic liver disease may be part of autosomal dominant polycystic liver disease (ADPLD). Autosomal dominant polycystic liver disease is considered rare autosomal dominant disease, with prevalence of 1/100,000-1,000,000. Without family history of polycystic liver disease, ADPLD is defined as the presence of more than 20 liver cysts with no renal cysts, however up to third of ADPLD may have small number of renal cysts without kidney function impairment. This case of a 73-year-old woman with symptomatic polycystic liver disease, and we performed cyst fenestration-deroofing via laparoscopic.
\end{abstract}

Keywords: Polycystic liver disease, autosomal dominant polycystic liver disease, cyst, treatment

\begin{abstract}
ABSTRAK
Penyakit hati polikistik dikarakteristikan dengan adanya lesi kista multipel pada hati. Kista hati seringkali hanya merupakan temuan insidentil, dengan potensi komplikasi yang jarang yaitu berupa perdarahan, infeksi, dan ruptur kista. Penyakit hati polikistik dapat merupakan bagian dari penyakit hati polikistik yang bersifat autosomal dominan. Penyakit hati polikistik autosomal dominan merupakan suatu penyakityang jarang ditemukan dengan prevalensi dilaporkan antara 1/100.000 hingga 1/1.000.000 kasus. Pada pasien tanpa riwayat keturunan penyakit polikistik, penyakit hati polikistik autosomal dominan didefinisikan sebagai ditemukannya lebih dari 20 kista hati dengan tanpa adanya kista ginjal, akan tetapi pada sepertiga kasus dapat ditemukan kista ginjal dalam jumlah sedikit tanpa adanya perubahan fungsi ginjal. Pada laporan kasus ini dilaporkan seorang wanita berusia 73 tahun dengan penyakit polikistik hati simptomatik, dan pada pasien dilakukan tindakan fenestrasi dan deroofing kista secara laparoskopik.
\end{abstract}

Kata kunci: Penyakit polikistik hati, penyakit polikistik hati autosomal dominan, kista, tatalaksana 


\section{INTRODUCTION}

Polycystic liver disease (PLD) is a rare disorder which may be found incidentally during abdominal imaging examination. PLD may be part of autosomal dominant polycystic liver disease (ADPLD) or extrarenal manifestation of autosomal dominant polycystic kidney disease (ADPKD); with the latter is more common. ${ }^{1,2}$

Several diagnostic criteria have been published to differentiate between ADPLD and ADPKD. Distinguishing ADPKD with ADPLD is important as the monitoring protocol, management, and prognosis may vary greatly. ${ }^{2}$ ADPKD is a multisystemic and progressive disease characterized by cyst formation in kidney and other organs which warranted routine renal function monitoring because the risk of developing end stage renal disease. ${ }^{1}$

Evaluation regarding the burden of PLD is warranted; because PLD is often mistakenly as benign disease and no treatment required. Treatment is indicated in symptomatic patients. Management of PLD consist of predisposing factor withdrawal, medical, and surgical therapy. Advancement in surgical field technology leads to development several surgical approaches for managing PLD. Liver transplantation is the only definitive cure for PLD..$^{1-3}$ Until now, there is no specific guideline published for PLD. Here, we present a recently symptomatic 73-year-old-female with PLD and acute cholecystitis.

\section{CASE ILLUSTRATION}

A 73-year-old woman came to our emergency department with fever and progressively increased right upper quadrant (RUQ) abdominal pain since 3 days before admission. The pain was rated as six out of ten, according to Visual Analog Scale. She complained of RUQ pain since one month ago, however the RUQ pain is progressively increased the past three days. The pain was described as dull, intermittent, aggravated with fatty food, and radiating to the back. She also complained nausea and vomiting. Her remarkable past medical history is controlled hypertension.

On physical examination, she appeared moderately ill with blood pressure of $130 / 90 \mathrm{mmHg}$, heart rate of 82 beats per minute, respiration rate of 20 times per minute, body temperature of $38.0^{\circ} \mathrm{C}$, and body mass index of $28.8 \mathrm{~kg} / \mathrm{m}^{2}$. Abdominal examination showed tenderness on RUQ, positive for Murphy sign and no sign of hepatomegaly. The initial laboratory examination revealed hemoglobin $12.1 \mathrm{gr} / \mathrm{dL}$, white blood cell $11,600 / \mathrm{mm}^{3}$, aspartate aminotransferase (AST) $35 \mathrm{U} / \mathrm{L}$, alanine aminotransferase (ALT) 23 $\mathrm{U} / \mathrm{L}$, alkaline phosphatase (ALP) $36 \mathrm{U} / \mathrm{L}$, albumin 3.04 $\mathrm{gr} / \mathrm{dL}$, total bilirubin $0.74 \mathrm{mg} / \mathrm{dL}$, gamma-glutamyl transferase (GGT) $10 \mathrm{U} / \mathrm{L}$, negative for hepatitis viral marker, normal electrolyte and kidney function. She was assessed for having acute cholecystitis. She was treated with intravenous (iv) ciprofloxacin $400 \mathrm{mg}$ bid, iv metronidazole $500 \mathrm{mg}$ tid, iv lansoprazole 30 $\mathrm{mg}$ bid, oral paracetamol $500 \mathrm{mg}$ tid, and amlodipine $5 \mathrm{mg}$ qd. On second day of admission, the fever was abated; she felt decreased pain on her RUQ abdomen. USG examination demonstrated multiple hepatic cystic lesion on both liver lobes sized $7.5 \mathrm{~mm}$ to 74.6 $\mathrm{mm}$ and simple left kidney cyst sized $25.7 \mathrm{~mm} \mathrm{x}$ $20.6 \mathrm{~mm}$. She was diagnosed with acute acalculous cholecystitis, due to no cholelithiasis was found on USG and positive for cholecystitis signs-symptoms, and polycystic liver disease suggestive for ADPLD. She was planned for abdominal computed tomography (CT) scan examination with contrast.

On the fourth day of hospitalization, she had mild RUQ abdominal pain with no fever. Laboratory result showed normal routine blood count. Contrast abdominal CT scan result showed multiple simple hepatic cystic lesions with more than 20 cysts on both liver lobes sized $7.5 \mathrm{~mm}$ to $74.6 \mathrm{~mm}$. Hepatic cystic lesions were found on all over liver segments except segment number 1 (Figure 1). Simple left kidney cyst sized $25.7 \mathrm{~mm}$ x $20.6 \mathrm{~mm}$ was also detected on CT scan. No biliary sludge, gallstone and occlusion on hepatic or portal vein were detected. Based on CT scan finding, she was diagnosed for having ADPLD with Schnelldorfer type C and Gigot type II.

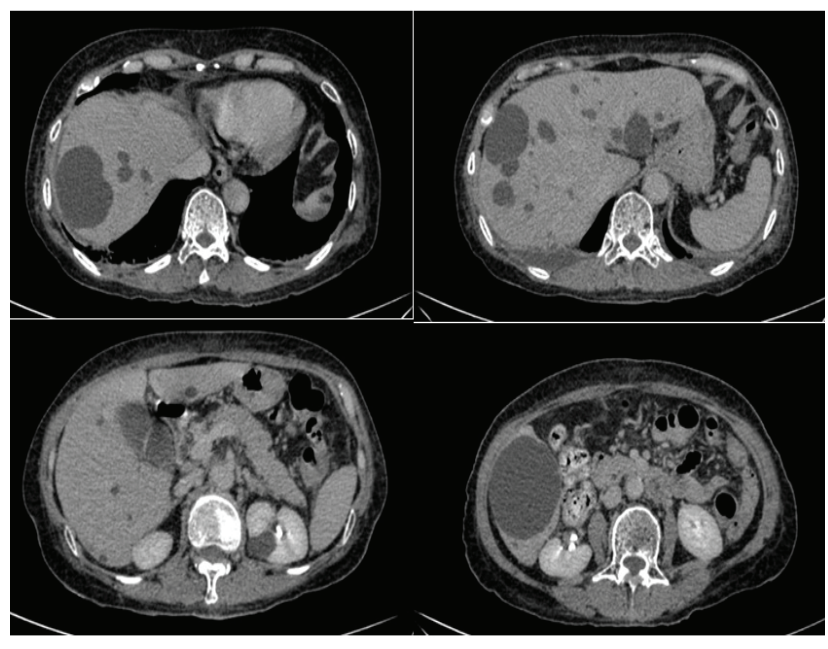

Figure. 1. Abdominal CT scan with contrast examination showed multiple simple liver cysts on both liver lobes and simple left kidney cyst. 


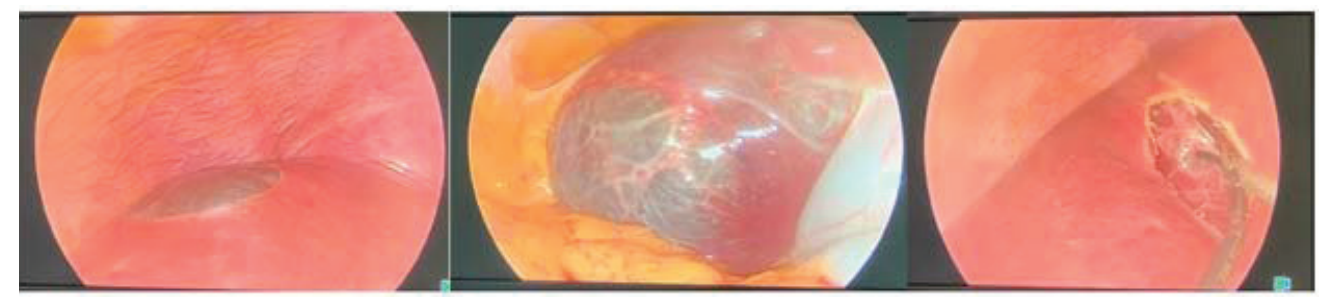

Figure. 2. Laparoscopic view showing the liver cysts $(A, B)$; after deroofing of the cysts (C)

She was consulted to digestive surgery department for further PLD management. After consultation, she was planned for cyst fenestration and deroofing via laparascopic electively. She was discharged on the fifth day and prepared for the surgery one week later. On second admission which occurred ten days after the first discharge, she underwent laparoscopic cyst fenestration and deroofing. Laparoscopic view confirmed CT scan finding (Figure 2).

The postoperative course was unremarkable and she was discharged on the third day of admission. The histopathology of liver cyst retrieved during surgery demonstrated benign liver cysts with sign of chronic liver inflammation. On 7 and 14 days of follow up visit at our liver clinic, she had no complaints.

\section{DISCUSSION}

PLD is defined by the detection of multiple fluidfilled liver cysts. As previously mentioned, ADPLD should be differentiated with ADPKD at the time of diagnosis. ${ }^{2}$ Widely used criteria for diagnosis of ADPLD and ADPKD relies upon the number of cysts in liver and kidney, patient's age, and whether there is familial history for polycystic disease or not. Without family history of PLD, ADPLD is defined as the presence of more than 20 liver cysts with no renal cysts, however up to third of ADPLD may have small number of renal cysts without kidney function impairment. ${ }^{1}$ Our patient had more than 20 liver cysts with simple cyst renal on left kidney and normal kidney function, therefore strongly suggested for ADPLD diagnosis.

ADPLD is considered rare autosomal dominant disease, with prevalence of $1 / 100,000-1,000,000$. ADPKD associated PLD is more common, with prevalence ranging between 1/400-1,000., ${ }^{3,4}$ ADPLD and ADPKD had been linked with different gene mutation. ADPKDP is caused by mutation of PKD $1(85-90 \%)$ and PKD2 (10-15\%) gene. ${ }^{2,4}$ ADPLD is linked with mutation of SEC63 and protein kinase substrate $80 \mathrm{~K}-\mathrm{H}$ (PRKCHS) gene. ${ }^{3}$ PRKCHS mutation, caused by mutation on short arm of chromosome 19, leads to hepatocystin deficiency and cystic formation. ${ }^{5}$
SEC63 which linked with short arm chromosome 6 mutation is crucial in regulating protein translocation across the endoplasmic reticulum membrane. Recent studies also found that LRP5 which may interact with Frizzled and lead to activation of $W n t / \beta$-catenin pathway and cell proliferation is responsible in cyst formation in ADPLD. ${ }^{2,5,6}$ In our hospital setting, genetic testing is not readily available. Until now, there is no valid recommendation to test patient with ADPLD as it may not impact the choice of management and up to $70 \%$ of patient with ADPLD may not have identifiable mutations. ${ }^{2,5}$ Several risk factors have been implicated with the growth of liver-cyst, such as female gender, advancing patient age, multiple pregnancies, use oral contraceptive drug containing estrogen, and the use of estrogen replacement therapy. ${ }^{1}$

Most of PLD patients (80\%) are asymptomatic. PLD is commonly found as incidental finding. ${ }^{1}$ Persistent RUQ pain after antibiotic course in our patient may attributed due to mass size of cystic liver lesions. Study reported that the growth of liver cyst is around $0.9-3.2 \%$ annually. ${ }^{6}$ The clinical features of liver cysts mainly related to the compressing effect of the large liver cysts mass and may presented as abdominal distension, early satiety, gastroesophageal reflux, inferior vena cava syndrome, dyspnea, jaundice, and Budd-Chiari syndrome. Other complications may be related with infection of liver cyst and rupture of liver cyst which may cause hemorrhage and severe acute pain. $^{7}$ There are two PLD-specific questionnaires to evaluate PLD-related symptoms and gauged the PLD disease burden, which are POLCA (PLD complainspecific assessment) and PLD-Q (PLD questionnaire). ${ }^{1}$

Abdominal USG is the first line of imaging modality to detect PLD as it readily available in most hospital settings, inexpensive, and no radiation. Liver cyst may show as homogenous anechoic fluid-filled round spaces in abdominal USG. Other imaging modalities are CT scan and MRI. MRI is superior in term of detecting small cyst and providing biliary tree and liver parenchyma condition compared to CT Scan. Liver cyst appears as non-enhancing, well circumscribed round walls with hypodense content. ${ }^{2,6}$ Radiological 
imaging is crucial in differentiating ADPLD and ADPKD, assessing the burden of cysts, and finally implicating the choice for best treatment. There are two standardized classification system has been proposed, which are Gigot Classification and Schnelldorfer classification. ${ }^{1}$ Gigot classification is using number and size of cysts, also the amount of residual normal volume. Schnelldorfer criteria incorporating patient's symptoms, cyst characteristics, number of relative normal liver parenchyma, the presence of portal or hepatic vein occlusion in preserved hepatic section. Schnelldorfer classification may give insight to choose appropriate management. ${ }^{1,2,6}$

Mikolajczyk et al proposed algorithm for the medical and surgical management of PLD. ${ }^{8}$ The first thing is evaluation whether there is consumption of steroid and estrogen based drug. Estrogen usage is implicated with accelerated growth of liver cyst, therefore avoidance is recommended. The next management step is to evaluate whether the PLD is symptomatic or not, treatment is only indicated in symptomatic PLD. Asymptomatic patient or type A Schnelldorfer PLD can be managed conservatively. In symptomatic PLD, burden of PLD should be evaluated using symptom based questionnaire as mentioned above and Gigot or Schnelldorfer criteria. The primary goal of medical and surgical treatment is to reduce symptom by reducing liver cyst size. ${ }^{1,8}$ Somatostatin analogue may be used to reduce liver cyst size in symptomatic patients with large total liver volume, e.g Schnelldorfer type C and D. ${ }^{1}$

There are several techniques of liver cyst mechanical removal such as cyst aspiration with sclerotherapy, fenestration, segmental hepatic resection and liver transplantation. Surgical management is reserved for advanced and symptomatic PLD. ${ }^{8,9}$

Aspiration with sclerotherapy is indicated for PLD patient with large dominant cyst $(>5 \mathrm{~cm})$ with one or few cysts and percutaneously accessible, and not suitable for operation. The most commons side effect is pain due to peritoneal inflammation and associated with high recurrence rate (up to $21 \%$ ). ${ }^{2,8}$

Cyst fenestration is the recommended surgical approach in patients with several accessible dominant cysts $(>5 \mathrm{~cm}) .{ }^{8}$ Nowadays fenestration which include cyst aspiration and surgical deroofing, with laparoscopic approach is the preferred method as this was done in our patient. However, laparoscopic fenestration is harder to reach posterior segment cysts or cyst located near the liver dome, therefore patients with cysts located in segments VI, VII, and VIII may need open fenestration. Possible surgical complications are postoperative ascites, pleural effusion and hemorrhage which may occur up to $20 \%$ of all cases and mortality rate of $2 \%$. Another consideration when choosing cyst fenestration approach is the potential of symptom recurrence and re-accumulation of cyst fluid which may reach $20 \%$. In order to minimize recurrence, minimally $50 \%$ of cyst surfaces should be removed during deroofing process. ${ }^{6,8,9}$

Segmental resection with fenestration may become alternative therapeutic approach whenever aspiration sclerotherapy and cyst fenestration alone is failed or not feasible. Patient whom classified as Gigot Type II and III may be the candidate. Hepatic resection was associated with high morbidity rates which range from $20-100 \%$ with morbidities like hemorrhage, surgical site infection, post operative pleural effusion and ascites, transient biliary leaks. Post operative mortality rate was considered low with number of $3 \%{ }^{2,6,8,9}$

Liver transplantation should be considered in severe form of PLD. ${ }^{1,10}$ Selection for LT candidate should be made carefully also weighing risk and benefit of the procedure. PLD patient with failed resection/resection or showing hepatic decompensation or on hemodialysis and categorized as Schnelldorfer type C and D may be considered for LT. Previous hepatic resection may complicate LT as it may related with post surgical adhesions. ${ }^{1,8,9}$

\section{CONCLUSION}

In summary, ADPLD is usually find as incidental finding on routine examination, however it should be differentiated with ADPKD as it has different prognosis and management. Burden of cyst should be assessed in every PLD patient. Therapy should only be reserved for symptomatic PLD.

\section{REFERENCES}

1. Patel A, Chapman AB, Mikolajczyk AE. A practical approach to polycystic liver disease. Clin Liver Dis 2019;14:176-9.

2. van Aerts RMM, van de Laarschot LFM, Banales JM, Drenth JPH. Clinical management of polycystic liver disease. J Hepatol 2018;68:827-37.

3. Masyuk TV, Masyuk AI, LaRusso NF. Therapeutic targets in polycystic liver disease. Curr Drug Targets 2017;18:950-7.

4. Willey CJ, Blais JD, Hall AK, Krasa HB, Makin AJ, Czerwiec FS. Prevalence of autosomal dominant polycystic kidney disease in the European Union. Nephrol Dial Transplant 2017;32:1356-63.

5. Janssen MJ, Waanders E, Woudenberg J, Lefeber DJ, Drenth JPH. Congenital disorders of glycosylation in hepatology: The example of polycystic liver disease. J Hepatol 2010;52:432-40.

6. Abu-Wasel B, Walsh C, Keough V, Molinari M. 
Pathophysiology, epidemiology, classification and treatment options for polycystic liver diseases. World J Gastroenterol 2013;19:5775-86.

7. Khan MS, Khan Z, Javaid T, Akhtar J, Moustafa A, Lal A, et al. Isolated polycystic liver disease: an unusual cause of recurrent variceal bleed. Case Rep Gastrointest Med 2018;2018:2902709.

8. Mikolajczyk AE, Te HS, Chapman AB. Gastrointestinal manifestations of autosomal-dominant polycystic kidney disease. Clin Gastroenterol Hepatol 2017;15:17-24.

9. Drenth JP, Chrispijn M, Nagorney DM, Kamath PS, Torres VE. Medical and surgical treatment options for polycystic liver disease. Hepatology 2010;52:2223-30.

10. Rodriguez PS, IV ASB, Gerber DA, Desai CS. Liver transplant for unusually large polycystic liver disease: challenges and pitfalls. Case Rep Transplant 2018;2018:4863187. 